\title{
Fatal Head Injuries in Royals that Changed the Course of History
}

\author{
Prasad Krishnan ${ }^{1, \odot ~ C h a n d r a m o u l i ~ B h a t t a c h a r y a ~}{ }^{2}$ \\ ${ }^{1}$ Department of Neurosurgery, National Neurosciences Centre, \\ Calcutta, West Bengal, India \\ 2Department of Internal Medicine, Peerless Hospital, Calcutta, West \\ Bengal, India \\ ${ }^{3}$ Department of Neuroanesthesiology, National Neurosciences \\ Centre, Calcutta, West Bengal, India
}

Indian J Neurotrauma 2022;19:54-56.

The classification and treatment of head injuries has been a source of concern for physicians even in ancient times as is evident from the Edwin Smith papyrus and the works of Hippocrates and it was known that such injuries could be serious and cause death. ${ }^{1,2}$ Over the ages, people (both plebeian and aristocrats) died due to head injuries either as a result of accident or assault (as in assassinations or in the battlefield). In most occasions of the latter, the exact nature of injury causing the death remains unknown. We have compiled a list (by no means exhaustive) of fatal head injuries among the royalty which changed the course of history (-Table 1), based on academic papers and resources we could find in the Internet like books and Wikipedia. ${ }^{3-20}$

A few of these lethal injuries were caused in the heat of battle (Harold Godwinson, Richard III), in a fit of rage (Ivan Ivanovich, Moctuzema II), during executions or assassinations (Seqenenra Taa, Julia Drusilla), and strangely enough some while going to watch or performing sporting events (Charles VIII and Henry II), or in the library (Humayun).

\author{
Address for correspondence Prasad Krishnan, MS, MCh, \\ Department of Neurosurgery, National Neurosciences Centre, $2^{\text {nd }}$ \\ Floor, Peerless Hospital Campus, 360, Panchasayar, Garia 700094, \\ Kolkata, West Bengal, India (e-mail: prasad.krishnan@ \\ rediffmail.com).
}

Whatever the cause, they were to be epoch making, as in a few instances, they resulted in the end of dynasties either by themselves (as in the case of the Anglo-Saxons and later the Plantagenets in England as well as the elder house of Valois in France), hastened it on account of a lack of a competent heir (Rurikids in Russia), or extinguished lineages (as in the Julio-Claudian dynasty). Yet others precipitated the decline and elimination of empires and conquests of entire continents (Aztecs in Mexico) or preceded brutal wars (religious wars of France between the Catholics and the Huguenots, the second battle of Panipat) or led to the displacement of large groups of people (Hyskos from Egypt may be the basis of the story of Exodus in the Old Testament).

Head injuries, therefore, may be not only be fatal for the person who suffers it but may have long-term catastrophic consequences for entire countries and large sections of the population who were in no way associated with the event. published online July 29, 2021
DOI https://doi.org/

$10.1055 / \mathrm{s}-0041-1732791$ ISSN 0973-0508
(C) 2021. Neurotrauma Society of India.

This is an open access article published by Thieme under the terms of the Creative Commons Attribution-NonDerivative-NonCommercial-License, permitting copying and reproduction so long as the original work is given appropriate credit. Contents may not be used for commercial purposes, or adapted, remixed, transformed or built upon. (https://creativecommons.org/licenses/by-nc-nd/4.0/).

Thieme Medical and Scientific Publishers Pvt. Ltd. A-12, 2nd Floor, Sector 2, Noida-201301 UP, India 
Table 1 List of fatal head injuries in royals that changed the course of history

\begin{tabular}{|c|c|}
\hline Name & Injury and events following death \\
\hline $\begin{array}{l}\text { Seqenenre Taa II, ruler of Southern Egypt } \\
\text { from 1558-1553 BC. }\end{array}$ & $\begin{array}{l}\text { Died either in battle with the Hyskos or was executed after being captured by them. }{ }^{3} \mathrm{CT} \\
\text { scan of his mummified body showed numerous head injuries, including fracture of the } \\
\text { frontal bone on both sides of the midline, right supraorbital fracture with bone loss, frac- } \\
\text { ture of the right orbit and zygoma, fractures of left skull base including mastoid process, } \\
\text { left occipital condyle and left side of the margin of the foramen magnum as well as right } \\
\text { temporal and parietal bones and right greater wing of the sphenoid. }{ }^{3} \text { His effort to drive } \\
\text { out the Hyskos (who were coexisting with the Egyptians till then) was finally completed } \\
\text { by his elder son Kamose (last king of the 17th dynasty) and Ahmose I (first king of the } \\
\text { 18th dynasty) and this resultant migration of the Hyskos is considered by some to be the } \\
\text { genesis of the old testament tale of the "Exodus" }\end{array}$ \\
\hline $\begin{array}{l}\text { Julia Drusilla (also called Drussila the } \\
\text { Younger), only legitimate child of Emperor } \\
\text { Caligula of Rome. }\end{array}$ & $\begin{array}{l}\text { She was killed when she was only } 1 \text { year old by having her "brains knocked out against } \\
\text { a wall" after her father was assassinated (January } 24, \text { AD } 41 \text { ). }{ }^{5} \text { ulia Drussila was the last } \\
\text { member of the Julio-Claudian dynasty and though Caligula was later succeeded by } \\
\text { Claudius and Nero, the dynasty eventually gave way to the Flavian dynasty. }{ }^{6}\end{array}$ \\
\hline $\begin{array}{l}\text { Harold Godwinson, the last crowned Anglo- } \\
\text { Saxon king of England ruled in } 1066 .\end{array}$ & $\begin{array}{l}\text { Killed by an arrow to his eye that entered his brain (as described in the Bayeux tapestry) } \\
\text { in the Battle of Hastings (October } 14,1066) .{ }^{7} \text { Although this is the commonly described } \\
\text { cause if his death, it has been disputed as inconclusive by some scholars. }{ }^{8} \text { With his death, } \\
\text { the Norman rule of England began under William the Conqueror (also called William the } \\
\text { Bastard). }\end{array}$ \\
\hline $\begin{array}{l}\text { Richard III King of England and Lord of } \\
\text { Ireland from 1483-1485. Last king of the } \\
\text { House of York. }\end{array}$ & $\begin{array}{l}\text { Died in the Battle of Bosworth (August 22, 1485). His exhumed remains showed in } \\
\text { addition to an arrow injury on his spine, eight injuries on his skull and facial bones. These } \\
\text { included a depressed fracture on the calvarium and a large area of bone loss at the base of } \\
\text { the skull in the right occipital region (presumably caused by a halberd), which along with } \\
\text { another skull base wound would have been fatal. }{ }^{9} \text { With his death, the Plantagenet dynasty } \\
\text { came to an end and England was then ruled by the Tudors. }\end{array}$ \\
\hline $\begin{array}{l}\text { Charles VIII of France } \\
\text { (Charles the Affable) } \\
\text { King of France from 1483-1498. }\end{array}$ & $\begin{array}{l}\text { While going to watch a game of tennis, he struck his head on the door. Later, after return- } \\
\text { ing from the game, he became comatose, and although he apparently regained speech } \\
\text { three times later, he died after } 9 \text { hours (April } 7,1498 \text { ). As he died at a young age of } 27 \\
\text { and had no surviving male heirs, the rule of France by the elder house of Valois ended } \\
\text { with his death and passed over to Orleans cadet house of Valois. }{ }^{10,11}\end{array}$ \\
\hline $\begin{array}{l}\text { Moctezuma (also called Montezuma), } \\
\text { Emperor of the Aztec Empire from } \\
1502 / 3-1520 .\end{array}$ & $\begin{array}{l}\text { Was arrested by the Spaniards under Hernan Cortez in his capital city of Tenochtitlan. } \\
\text { While pleading to his populace to allow safe passage for the Spaniards out of the city, he } \\
\text { was hit on the forehead by a stone projectile (thrown from a sling) by one of his infuriated } \\
\text { subjects who were against the Spaniards and died three days later (June } 29,1520 \text { ). Within } \\
\text { a year, the Spaniards had conquered the Aztec empire. }{ }^{12}\end{array}$ \\
\hline $\begin{array}{l}\text { Nasir-ud-Din MuSlammad (Humayun) the } \\
\text { second emperor of the Mughal Empire from } \\
1530-1540 \text { and again 1555-1556. }\end{array}$ & $\begin{array}{l}\text { Fell from the steps of his library and struck his temple on a stone while he was trying to } \\
\text { get up after kneeling in response to a muezzin's call for prayer when his foot got caught } \\
\text { in his robes. He was apparently unconscious initially; later, regained his speech but again } \\
\text { worsened and died after three days (January } 27,1556) .{ }^{13} \text { Following his death, his minor } \\
\text { son Akbar was appointed king and had a turbulent early phase where he had to fight off } \\
\text { Raja Himu and later Sikandar Shah Suri who attempted to dislodge the fledgling empire. }{ }^{14}\end{array}$ \\
\hline Henry II, King of France from 1547 to 1559. & $\begin{array}{l}\text { Suffered head injury in a jousting tournament held to celebrate the peace treaty ensuring } \\
\text { the end of the Habsburg-Valois war (Peace of Cateau-Cambrésis). } .^{15} \text { The lance of oppo- } \\
\text { nent splintered against his armor and fragments entered his right eye. After a transient } \\
\text { loss of consciousness, he was able to forgive his opponent and walk. Over time, he had } \\
\text { worsening headaches and episodes of confusion. Later, he had focal seizures, became } \\
\text { unconscious with worsening respiration, and died after } 10 \text { days (July } 10,1559 \text { ). He was } \\
\text { the first king to undergo an autopsy that revealed contrecoup contusions in the occipital } \\
\text { lobe with liquefactive necrosis and an acute subdural hematoma that was becoming } \\
\text { chronic.16,17 He was succeeded by ineffectual rulers and this eventually resulted in the } \\
\text { French Wars of Religion (between Protestants and Catholics) where up to } 3 \text { million people } \\
\text { perished. }{ }^{18}\end{array}$ \\
\hline $\begin{array}{l}\text { Ivan Ivanovich, heir apparent to the throne } \\
\text { of Russia, son of Ivan the Terrible. }\end{array}$ & $\begin{array}{l}\text { Was beaten by his father the Tsar Ivan IV (Ivan the Terrible) with the royal scepter (when } \\
\text { he confronted his father who had beaten his wife, causing the miscarriage of his unborn } \\
\text { child) and became unconscious with a bleeding wound to the temple. He regained } \\
\text { consciousness briefly, forgave his father, but again lapsed into coma and died } 4 \text { days later } \\
\text { (November 19, 1581). The throne thus passed to his feeble-minded brother with whose } \\
\text { demise the Rurikid dynasty came to an end and plunged Russia into a period of lawless- } \\
\text { ness and anarchy called the "Time of Troubles" till the Romanov dynasty took over. }\end{array}$ \\
\hline
\end{tabular}




\section{Conflict of Interest}

None declared.

\section{References}

1 Kamp MA, Tahsim-Oglou Y, Steiger HJ, Hänggi D. Traumatic brain injuries in the ancient Egypt: insights from the Edwin Smith Papyrus. J Neurol Surg A Cent Eur Neurosurg 2012;73(4):230-237

2 Panourias IG, Skiadas PK, Sakas DE, Marketos SG. Hippocrates: a pioneer in the treatment of head injuries. Neurosurgery 2005;57(1):181-189, discussion 181-189

3 Saleem SN, Hawass Z. Computed tomography study of the mummy of King Seqenenre Taa II: new insights into his violent death. Front Med (Lausanne 2021;8:637527

4 Wikipedia contributors. Sources and parallels of the Exodus. Accessed April 23, 2021 at: https://en.wikipedia. org/w/index.php?title=Sources_and_parallels_of_the Exodus\&oldid $=1019100283$

5 Wikipedia contributors. Julia Drusilla (daughter of Caligula). Accessed April 23, 2021 at: https://en.wikipedia.org/w/index.php?title=Julia_Drusilla_(daughter_of_ Caligula)\&oldid=1017959859

6 Wikipedia contributors. Julio-Claudian dynasty. Accessed April 23, 2021 at: https://en.wikipedia.org/w/index.php? title=Julio-Claudian_dynasty\&oldid=1017069413.

7 Wikipedia contributors. Harold Godwinson. Accessed April 23, 2021 at: https://en.wikipedia.org/w/index.php?title=Harold_ Godwinson\&oldid=1018084026

8 Wikipedia contributors. Bayeux Tapestry. Accessed April 23, 2021 at: https://en.wikipedia.org/w/index.php?title=Bayeux Tapestry\&oldid $=1018177130$

9 Appleby J, Rutty GN, Hainsworth SV, et al. Perimortem trauma in King Richard III: a skeletal analysis. Lancet 2015;385(9964): 253-259
10 Wikipedia contributors. Charles VIII of France. Accessed April 23, 2021 at: https://en.wikipedia.org/w/index.php? title=Charles_VIII_of_France\&oldid=1017012330.

11 Scoble, A R, The Memoirs of Philip de Commines. Vol 2. London: Henry G. Bohn; 1856 283-84

12 Sanchez GM. Did Emperor Moctezuma II's head injury and subsequent death hasten the fall of the Aztec nation? Neurosurg Focus 2015;39(1):E2

13 Stewart C, The Tezkereh Al Vakiat or Private Memoirs of the Moghul Emperor Humayun. London: W. Nicol; 1832120

14 Wikipedia contributors. Akbar. Accessed April 23, 2021 at: https://en.wikipedia.org/w/index.php?title=Akbar\&oldid= 1019341040

15 Wikipedia contributors. Henry II of France. Accessed April 23, 2021 at: https://en.wikipedia.org/w/index.php?title= Henry_II_of_France\&oldid=1019286789

16 Kean S, The Tale of The Duelling Neurosurgeons. The History of the Human Brain as Revealed by True Stories of Trauma, Madness and Recovery. London: Transworld Publishers; 2015 27-52

17 Norwich I. A consultation between Andreas Vesalius and Ambroise Paré at the deathbed of Henri II, King of France, 15 July 1559. S Afr Med J 1991;80(5):245-247

18 Wikipedia contributors. French Wars of Religion. Accessed April 23, 2021 at: https://en.wikipedia.org/w/index.php?title= French_Wars_of_Religion\&oldid=1016242419.

19 Wikipedia contributors. Tsarevich Ivan Ivanovich of Russia. Accessed April 23, 2021 at: https://en.wikipedia. org/w/index.php?title=Tsarevich_Ivan_Ivanovich_of_ Russia\&oldid $=1006168365$

20 Wikipedia contributors. Time of Troubles. Accessed April 23, 2021 at: https://en.wikipedia.org/w/index.php?title= Time_of_Troubles\&oldid=1012342328 